\title{
Some aspects of the industrial revolution in Western Europe
}

\author{
Marion I. Newbigin D.Sc. (Lond.)
}

To cite this article: Marion I. Newbigin D.Sc. (Lond.) (1918) Some aspects of the industrial revolution in Western Europe, Scottish Geographical Magazine, 34:7, 251-263, DOI: $10.1080 / 14702541808555297$

To link to this article: http://dx.doi.org/10.1080/14702541808555297

曲 Published online: 30 Jan 2008.

Submit your article to this journal $₫$

Џll Article views: 38

Q View related articles 5 
re-establish British industries to which they have devoted their lives and energies.

Money will have to be provided for railways, roads, and other public works. New industries, which bave received such a sudden check, will have to be fostered, and if necessary assisted financially, while perhaps, above all, the question of the wants, education, and general requirements of our native subjects will require to be carefully considered and dealt with throughout Eastern Africa.

\title{
SOME ASPECTS OF THE INDUSTRIAL REVOLUTION IN WESTERN EUROPE.
}

\author{
By Marion I. Newbigin, D.Se. (Lond.).
}

ALt the chief states of the world, with the partial exception of China, have been profoundly influenced during the last century or so, by that great series of economic changes to which the term Industrial Revolution is conveniently applied. The effects of these only manifested themselves slowly, and were far from occurring simultaneously throughout the civilised world, so that it is impossible to assign an exact date to the industrial as we can to political revolutions. Nevertheless, there are a few outstanding events which it is well to bear in mind in discussing the subject, for they indicate at least the starting-point of the new conditions.

Note first that, put in briefest form, those changes in industry and commerce which were so profound as to merit the name of Revolution were two in number. In the first place, the power of production was suddenly and enormously increased. Second, such improvements were made in means of transport and of communication, that, compared with older conditions, space seemed to be almost annihilated. Increased production first manifested itself in the textile industries, and depended upon a whole series of inventions, which reacted strongly upon each other. Hargreaves invented his spinning-jenny in 1764, and patented it in 1770 ; Arkwright patented his water-frame in 1769 , and Crompton his mule in 1779 , while Cartwright's power-looms were patented in 1785 and 1787 . Watt was working at his steam-engine during almost the same period (1769-82), and Whitney's cotton gin, which for the first time permitted raw cotton to be put upon the market in large quantities, was patented in America a fow years later, in 1794.

The great improvements in transport were, of course, due to railways and steamships, themselves depending ultimately upon Watt's steamengine, and the use of coal. The first steam-railway for general purposes, it will be remembered, was the Stockton-Darlington line, opened in 1825. The first practically successful steamboat was Symington's, patented in 1801, though it was some years later before the problem was really solved economically. The utilisation of the 
force of electricity in telegraphy by wire post-dated railways by about twenty years.

Broadly speaking, then, we may say that the inventions which made the industrial revolution possible were worked out in the latter part of the eighteenth and the early part of the nineteenth century. Now the outbreak of the great war marked the definite close of a particular: period of human history. What the future holds we do not know; but it is at least certain that the world to which peace comes will be in many respects a changed world. It is thus possible now to look back upon what we must regard as at least the completed first stage of the industrial revolution, a stage which may be regarded as lasting for the hundred years between Waterloo and Serajevo. It is proposed here to consider some facts connected with the different forms which the process of industrialisation took, in this country and on the continent, throughout the period, and to discuss them in relation to geographical conditions. and to the war: to the war, for it would almost seem as if the great conflict was as inevitable a consequence of the industrial revolution as was the Terror of the French one: to geographical conditions, for not only has industry been everywhere influenced by place relations, but the avowed purpose of the Allies, the defence of the small nationalities, is based fundamentally upon a geographical conception.

In order to keep the survey within reasonable bounds we shall limit ourselves to the three countries of Great Britain, France, and Germany. The United States are left out of consideration because the conditions there were complicated by a number of factors which do not present themselves on this side of the Atlantic. Among these were the existence, during the period, of vast areas of virgin lands, which gave, with the help of the new forces of machinery, a capacity for surplus food production on a scale of which the world had had no previous experience. Another special feature was the almost limitless supply of adult immigrant labour, unorganised, unspecialised also in most cases, to which the Old World offers almost no analogy. No analogy on the same scale, that is to say, for Germany in the years before the war was demanding and obtaining cheap and unorganised Itakian, Polish, and Russian labour in a somewhat similar fashion.

Beginning with Groat Britain, the first and most obvious point, and one that has been often emphasised, is that this country for a long period led in the process of industrialisation. The cause was in part. historical, for the period at the end of the eighteenth century and the beginning of the nineteenth, that which saw the development of the great inventions, was one of great turmoil on the continent of Europe. Our insular position enabled us, despite our participation in the Napoleonic wars, to obtain a start in the establishment of factories. During the same period, the United States formed a new, still thinly peopled country, not ready for industrialisation. Further, the position and abundance of our coalfields, the ease with which the coal could be won, our predominance on the seas, and the inventive genius of the British people, were all factors of importance.

The iron industry in any country is often taken as an index of the 
industrial and commercial status of that country. Judged by this standard, the most striking feature of the years preceding the war was the fact that this country had definitely lost its supremacy. In 1890 the production of iron and steel in the United States for the first time surpassed that of Great Britain. Ten years later, in 1900, the lead of the United States had liecome very marked, while the production in Germany nearly equalled that here. By 1910 Great Britain had definitely fallen into the third rank. Clearly, then, if during the first two-thirds of the period under consideration the dominant fact in industry was the supremacy of Great Britain, during the last third it was the rise of the United States and Germany into the front rank.

Let us look next at the special geographical conditions which have influenced the course of industrialisation in England. The first and most obvious point is that the coalfields, and thus the areas best suited to industry, aro remote, so far as the small total area of the country allows, from the old national centres. Placed on the margins of the uplands, both northern and western, they lie in areas which had not previously counted for much in the national life.

Mr. Fdward Hutton, an author to whom the Old and Merry England of pro-industrial days makes a strong appeal, has suggested that the real England is the area south of a line between the Thames and the Severn. The statement is extreme, from any point of view; but we may admit at least that the England of tradition, the England of the Elizabethans, the region which saw the fine flower of our literature, in which wealth was stored, where a state of well-being for a certain proportion of the community was possible, was the England of the scarplands and the plains. This fact was deeply implanted in the minds of the community - so deeply rooted that even to-day all the experience of the material wealth to be won on the coalfields has hardly eradicated it. At the time of the oubbreak of war the richer nnembers of the new industrial communities were just beginning to evolve a tradition of their own, putting out roots, as it were, in the new soil.

The fact that London is at once the repository of the national traditions and ideals, and, under the now conditions, a city of commerce rather than primarily of industry, has, of course, accentuated the power of the older ideals to make a stand in the face of the new. An American author has said that one of the facts which strikes his countrymen most, when they come to make pilgrimages to old world shrines, is that the great publishing houses of London, whose names are world-famed, are mostiy lodged in what an unkind observer might describe as slum dwellings-certainly not in magnificent sky-scrapers! The fact is perhaps suggestive of much-of among other things, a certain south country contempt for the display of wealth, a conviction that that is better suited for the new cities of the coalfields than for a metropolis with an ancient tradition.

It seems at least true to say that England, despite wbat some would call her early infection with the virus, has never become completely industrialised. Fven in her industries, her younger competitors recognise something of the haughtiness of the vienz" monde in face of "up-to- 
date" methods. Thus, as contrasted with the old gibe at a nation of shopkeepers, it is eurious to note that a recent French author, M. Engerand, contrasting English with German industrialists, describes the former as "vrais gentilshommes de l'industrie," who "exploitaient leurs mines et forges en gentlemen farmers" ( $L^{\prime}$ Allemagne et le Fer, pp. 220 and 221).

In Scotland the conditions are somewhat similar, for the traditions of the east, based upon the occupation of fertile agricultural lands, and upon an old connection with the continent, and contring round Edinburgh, have maintained themselves as against the new wealth and the new etrength of the west, centring round Glasgow.

This conviction that national and individual well-being come from the land is, of course, all but universal in old states, and not peculiar to Great Britain. But the course of industrial development here was profoundly influenced by our sea-power, and, associated with this in origin, the holding of overseas possessions in climates suitable for European sottlement.

As to the first point, our splendid ports, our seafaring population, our geographical situation, made it possible to develop foreign trade on a large scale so soon as the new factories furnished material for exchange, while those factories in their turn could only be fed by raw material brought from a distance in British ships. The seafaring instincts, again, combined with the great development of shipping, meant, as it has meant throughout our history, an absence of insularity. The dangers of limitation to a small island were corrected by free intercommunication with the wide world, and that free intercommunication brought tolerance, practical common sense-what Naumann, in his Mitteleuropa, calls the Englishman's elasticity, his calm adaptability, his unshakable self-confidence. Our dominance on the seas has diminished, in short, the risks of narrow outlook due to life on a small island, by giving us a world environment in addition to the limited local one.

The constant swarming-off, during the period under discussion, of the young and energetic members of the community to the new lands across the seas, has had precisely the same effect. Both have checked the tendency to become intoxicated by the new power which machinery gave to production on a hitherto unprecedented scale; have given us other interests, other capacities also, than that of mere production.

Just as through all the period under consideration, the young man who rebelled against following his father to the mill, the factory, or the counting-house could always "run away to sea," so also he would throw off the yoke of tradition in another way, and begin life for himself in a new world. But-and this is the essential point-his departure was not really a breaking of ties. In that new world he was still linked to the old by a bond whose strength lay in its looseness. No necessity was laid upon him, as upon the German in the United States or the Argentine, to make a definite choice between the new and the old; his departure strengthened rather than weakened the mother country, and the fact that at home the door was always open made for a freer life there. In Germany, says Naumann in his most suggestive chapter on 
the industrialised peoples of Germany, "a strong net is woven round the individual." To him the ideal is that the net should ever be woven tighter and tighter. "The insertion of the individual ego into the joint ego is our special ability" (Central Europe, English translation, p. 116). Here, on the other hand, the individual has always been able to slip through the meshes of the net, and the specialisation of the individual has reacted strongly upon the community.

But though from one point of view the phenomenon of emigration has meant the escape of the individualised, from another it has been necessitated by the intermittent presence of a surplus population. For, though it may not perhaps be obvious at first sight, the great increase in production due to the industrial revolution has affected population as well as goods. Over-production, of which we shall have to say something in a moment, has tended to occur in both cases. The decay of agriculture, due partly to the enclosure system, partly to industrialism, and partly to the development of the virgin lands overseas, also tended to produce a surplus of labour which had to find an outlet.

It is a familiar geographical deduction that, in the East, rice-growing tends to be associated with a dense agricultural population; for the more rice is grown the more people can be fed, the more children born the more rice can be grown. But the same thing is true also of industry, which both demands and supports a large population. Both in England and Scotland the increased population of the coalfields was obtained by attracting agricultural labourers, at first from the poor lands, where there was a natural surplus of labour, and later from a wider area. But this primary source of supply would not have been sufficient without an increase in the birth-rate. In the early days, before factory legislation, child labour was, of course, extensively employed. Now whereas on the land a youth could not hope to marry till he had attained a man's strength, in the factories strength and maturity were of less significance, and since men, women, and children were alike wage-earners, early marriage, with prolifie child-bearing, and many attendant evils, became the rule. In other words, the necessary increase in the population to enable the change from a predominantly agricultural community to a predominantly industrial one to take place, arose in the country itself. As we have already stated, this was not the case in America.

Logically, it might seem that once caught in the industrial net in this fashion there was no escape. The new factories could produce thousands of yards of cotton cloth, the new rolling mills thousands of tons of iron rails. But for the task of production thousands of operativer were necessary, and if these were supplied, then they could be fed by food brought across the seas from the virgin lands in the new steamships, paid for with those cotton goods and iron rails. The social conditions multiplied the labourers as the industrial conditions multiplied the goods; in both cases over-production was always liable to occur, with consequent poverty and misery.

That this self-adjusting mechanism did not end in a crash in this country during the period of her lead was probably, as we have sug- 
gested, partly because there was more than one way out of the net, and partly because the old tradition made a bold stand in the face of the new. There was here a constantly repeated and constantly increasing revolt against the notion that man's mission in life is to produce cotton and iron goods, to sell them, and to beget many children to produce and sell them in their turn. To the young people of the successive generations, and more especially to those born in families where the old tradition of poverty and narrowness of life had faded, came always the question et après? When the cotton is woven and the ships built, what next? Does continued production alone bring the satisfaction which all living things seek in life?

In the years before the war this silent and unnoticed revolt was being stadily stimulated by the phenomenon of over-production, which, in so far as it affected goods, was evaking on a now form.

In the earlier days, more especially while Great Britain remained the only great industrial nation, the world's power to absorb seomed to keep pace with, or even to exceed, industrial production. Overproduction then seemed, and perhaps was, a local condition due to inadequately organised transport, to the fact which we have already noticed that improvement in transport and communication lagged quite perceptibly behind improvements in the machinery of production. Thus many maintained that the customers existed somewhere, and that it was only a question of reaching them. This led again, in the fulness of time, as the near markets became exhausted, or were protected by the individual states in the interests of their own developing industries, to the search for colonies, as regions wholly unindustrialised, but capable of furnishing markets and raw material for new manufactures.

But there is another aspect of over-production also which was implicit in our contemptuous phrases of "made in Germany," and "Brummagem goods." Man had acquired a new skill, a new technique. Employed legitimately anough at first in making with increased ease, and $a t \&$ reduced cost, goods of which the world will always have need, it was boing increasingly used in the manufacture of objects with no particular use and no special beanty. If Cermany was employing the skill and patience of her workers in such forms of activity to a marked extent, yet we must not forget that we had for long been doing it also, if on a smaller scale. The war, said a French newspaper writer in a passionato outburst in Angust 1914, was started by Germany in order to force the world to buy the "pacotille" which her factories turn out yearly in thousands of tons. But in this, as in some other respects, Germany was only carrying cut to their logical conclusion principles of action which other nations had been practising before her. The soulless machines every were were turning out automatically necessities and useless rubbish on a vast scale. New operatives were wanted to produce, new markets to absorb, and the world as a whole moved steadily, though with a different momentum in the separate states, towards the great catastrophe.

But if over-production, and the consequent rivalry for markets, was one of the causes of the catastrophe, there was another, less obvious, but in some ways probably even more important. This depends upon the 
development of steamships and railways, and the utilisation of the new fores of electricity, which enabled man to transport goods in a hitherto unknown fashion, to communicate almost in a moment with the uttermost ends of the earth. The effect was, apparently, to emancipate him from the control of his immediate environment, to break the bonds which had previously linked human groups to the physical conditions under which their lives were passed. But it is this link which maintains-perhaps even produces-the individuality of the separate groups. Just as among animals specific differences, however they arise, seem to be preserved by environmental differences, so individuality among nations and communities is closely linked to the differences in soil, in climate, in productions of the areas which they respectively inhabit.

Before the war we were witnessing the development of international capitalism and, as the mirror image of this, that of international socialism. To the biological warning that survival depends upon the capacity for variation, itself controlled by local environmental conditions, and arising in response to them; to the warning of the artist and creative thinker that it is not the citizen of the world, but he who can absorb and transmute local impressions who is the producer of that which is distinctively human, both turned a deaf ear. Both for different reasons, and by different methods, were striving to break down the old national dividing lines, to eliminate the effects of local environment. Both were preparing the way for the great attempt to establish the hegemony of the world.

If the notion that human life was losing its old local basis was spreading fastest in Germany, it was obvious elsewhere also. In Germany some of the effects were visible in, for example, the great city of Munich, where wealth was being spent on an "art" which consisted in a servile copy of the art, especially the architecture, of another nation. In other parts of Bavaria, also, an old peasant industry, which had originated in situ, was being replaced by a wholesale manufacture of toys which combined a crude barbarity of conception with much teehnical skill. Wbole communities were contentedly engaged in producing monstrosities which satisfied no natural instinct in their makers, and were calculated to inflict irreparable injury on the taste of the children for whom they were intended.

It is here that we come, by way of contrast, to the special feature of the life of France. In our own country, because of our control of the seas, and our extensive foreign trade, the bond of local place relations has been loosened, though to a less extent than in Germany. France, with a far larger area, a greater variety of climate and soil, has always had better marked local groupings. With a much lower degree of industrialisation, a far less developed foreign trade, these local relations have been less modified.

It may be true, as has been stated, that a French Minister of Education can take his watch from his pocket, and say,-At this moment every child in France is engaged upon such and such a task. But if he were wise, he would add that, when work is over, each child will go home to a house and a meal both equally stamped with the print of the local

VOL. XXXIV. 
place conditions. Secure in the unifying effect of Paris and its ideals, the French are able to allow these local conditions to exert their full effect. They realise clearly that the nation's life is richer, not poorer, when national patriotism is based upon local patriotism, that a man should be a citizen of his "pays" first, and of his country second, that he should contribute to the whole an individualised strand. And are not French literature, French art, French influence upon the world, avidence that they are right?

If we drank of the new wine of industrialism early, and have had time for the most part to learn that it does not suit all palates-that it is a dangerous draught for the docile, and arouses strong revolt in the highly individualised, it is the great gift of France to the world that vast tracts of her country have felt no desire to drink at all, have preferred the produce of their own vineyards and orchards, their Norman cider, their Burgundy, the vintages of Provence and of Languedoc. It is a good omen for the future, also, that the two countries should be united at the moment in the attempt to defend the small national entities, to resist the great attempt to standardise the world.

Let us turn next to a consideration of the effect of industrialisation in Germany, and its bearing upon the state of mind which produced the war. Here we shall rely chiefly upon the statements contained in Noumann's Mitteleuropa, which has been already reviewed here, ${ }^{1}$ and is as remarkable for its candour as for its ability.

In discussing Naumann's views it may be well to dismiss from our minds, so far as may be, all thought of the barbarities which have marked the German conduct of the war. These barbarities have been, almost without doubt, deliberately ordained by the military caste, and shat in the bope of intimidating the neutrals and the weaker allies. At home, dealing for the most part with docile, easily-cowed peoples, the ruling powers in Germany have found brutality profitable. They assumed that it would prove a useful weapon also against peoples of stronger individuality, who had enjoyed a long period of freedom. In this they were wrong; but as the path upon which they had started is one in which it is difficult to turn back, they have gone on, hoping always to find sooner or later the ultimate frightfulness destined to cow the world. So far their methods have stimulated resistance instead of crushing it, and have thus failed lamentably in their purpose. But it should not be forgotten that if, for the nations as well as for the individuals in each, it is the German atrocities which afford the strongest argument for continued resistance, that which gives strength to the spirit when the weak flesh quails, yet there is something to fight against behind and beyond the atrocities.

Had the German Military Staff adhered to the Hague Convention, instead of violating both it and all the natural human instincts at every turn, there would still, as Naumann quite clearly if tacitly recognises, have been grounds for revolt against the doctrine which she wishes to impose upon the world. The very fervour of his appeal to Austria- 
Hungary, the frankness with which he sets forth the anti-German point of view, is an acknowledgment that, within the Hapsburg monarchy, no less than elsewhere, there are those who are strongly revolted by the modern German ideal. This ideal, in may be repeated, is the watchword of the industrial revolution carried to its furthest logical conclusion. Using to its full the analogy implied in the word Revolution, we may say that while the leaders in this country have always tended to be Girondists (or "gentilshommes d'industrie"), the later German industrialists belong to the Mountain-are extremists rather than moderates-and so far they have carried their countrymen with them.

But both parties, Extremists as well as Moderates, are represented in other countries as well as in Germany, and in considering Naumann's opinions it is well to forget their immediate application to Austrians and Hungarians, and to consider them as a general exposition of the extreme position. He himself, be it noted, with great simplicity, indicates that if Austria-Hungary can be persuaded to attach itself firmly to a Central European Federation, other recalcitrant nations can be readily compelled to come in. Naumann is frankly making a bid for world supremacy for Germany-"We shall enjoy our golden age, as other conquering nations in other ages and with other abilities and excellences have done before us. Our epoch dawns when English apitalism has reached and overstepped its highest point . . Germany, foremost in the world!" (p. 123).

This is definitely an ideal, and one ideal can only be overthrown by another. Is the world destined to be subjugated by German industrialism, which implies an entire suppression of individuality, of personality, of the effect of local place relations, and thus of nationality? If not, how can individuality be preserved? This is the essence of the problem.

In his chapter, entitled in the original "Das mittelouropaeische Wirtschaftsvolk," translated as "The Economic Life of Central Europe," Naumann begins with a sketch of life in North and Central Germany during the eighteenth century, before the beginning of industrialisation. The description, broadly speaking, follows lines similar to those which would be followed if the account had referred to the poorer parts of this country, and need not be summarised here. The change from that aondition to the present one Naumann ascribes, in characteristically Gorman fashion, to compulsory education. "Something developed in them [i.e. in North and Central Germany] which in course of time was to outdistance in method and efficiency the already existing capitalistic civilisation of earlier growth; a homely skill in the popular ability to transform dreamers into workers by the aid of letters and memory sxercises" (p. 112). We say characteristically German, because it is obvious that the first essential of the transformation was the invention of the machinery which was to give the workers their new power of production. But the great inventions were largely British, and are therefore left out of account in the text.

The result of the transformation was the development of the 
specially German method of work- "the transition to the impersona capitalism of the second stage." Naumann devotes some space to elaborating this point, using a number of illustrations, some of which have been already widely quoted in this country. He speaks of the special German characteristic as "organising ability," but he means more than this, for he says frankly that to the non-German the special German type means "the death and surrender of the individual soul." Further, he lays much stress upon the fact that the movement is not only a capitalist movement from above; it affects labour and the labouring classes as much as employers. "The idea of a super-personal economic leadership of the masses in work and in the sale and consumption of its products is prevalent and becomes a mere matter of course. In this the German working classes differ from all the Latin nations, for what in France and Italy is called socialism is indeed related in word and theory to the German workmen's unions, but has none of the sternness of inward determination which has been attained by our social democrats, or even by other unionist groups." $\mathrm{He}$ goes on to say that no class or section of the community escapes-c "even artists," he says expressly. Finally, he sums up by saying that "the actual fact that we possess the most theoretical labour movement in the world is part of the picture of German economic life. This working class in combination with its educated employers, with our syndicate leaders, with our civil service and officers, does not offer the most charming and amusing society possible, but does constitute the most practical, safe, and durable ${ }^{1}$ human machinery. This living national machine goes its way whether the individual lives or dies; it is impersonal or super-personal, has its friotions and interruptions, but is as a whole something that has never come to pass exactly in this way before; it is the historically developed German character" (p. 121).

Since Naumann wrote these words the world has had an opportunity of observing the effect of an organised attempt to introduce this "machinery" into a country where industry plays a relatively small part in the national life-for the leaders of the Bolsheviks have been profoundly influenced by German thought. The result, so far, has been to show that, even when it is introduced for the alleged benefit of "labour," it becomes at once an autocracy of the most virulent type. The people of Russia are not to be allowed to have the social conditions which they themselves want, which they as individuals and groups can evolve in accordance with their own conditions of life. They are to have a "theoretical" millennium imposed upon them from above, and to bo shot down by machine-guns if they object.

Our naïve author goes on frankly to admit that the industrialised superstate is necessarily the state militant: "The war was really only a continuation of our previous life with other tools, but based on the same methods. . . . If our opponents like to label this intrinsic connection between the work of war and peace as 'German militarism, we can only regard this as reasonable, for Prussian military discipline 
influences us all in actual fact, from the captain of industry (Industrieadmiral) to the maker of earthworks (Erdarbeiter)" (p. 122). He does not-it could not perhaps be expected that he would-allude to the fact, which has been noted by the thoughtful here, that when the military party insisted upon the clumsy weapons of guns and poison gas, as against the more dangerous means at the disposal of the industrialists, they were running great risks. Had the terrorists of Prussia not insisted upon open war, civilisation might have been choked before the world was fully aware of the stranglehold of the superstate.

We have emphasised Naumann's astonishing candour and simplicity. It can be readily understood that these qualities enable him to realise at once that the picture which he presents is not at first sight an alluring one to possible partners. To persuade the Austrians and Hungarians to permit themselves to be caught in the wheels of the great mechanism he relies chiefly upon two arguments.

The first is that the South German states, before 1870, showed the same reluctance to unite with Prussia, as he suspects to exist to-day aeross the German frontier when a larger union is in contemplation. He admits, by implication if not by direct statement, that those states had a life of their own, based upon local place relations, had ideals which were not Prussian ideals. Yet to-day, he says, their particulariom has died away as a result of the experience of the material prosperity which union has brought. In his own phrase they have sold their soul to Prussia: but, as he proudly implies, in contradistinction to the action of the traditional dominant party to that form of transaction, Prussia has punctiliously paid up in gold-in current coin indeed, not the fairy gold of legend which turns to dust in its possessor's hand. As a consequence of this improvement on medirval methods in South Germany to-day, "no one wants to put an end to the joint development, no one."

His second argument may be thought by some to show the cloven hoof. It is in brief that Austria-Hungary has no shoice-a somewbat dangerous argument to use to a proud people! As he quite justly says the old pre-industrial condition, especially in the poorer regions, meant a very limited prosperity; limited in amount, and even more limited in distribution among the members of the community. We cannot go back, he says, and here there is no doubt that he is right. Ruskin and his followers were leading a forlorn hope. To abandon the new powers which man's ingenuity has won because they can be abused is rank folly. The question whether this is the only alternative to the German type of industrialism Naumann does not consider; that this represents the last word in social evolution must appear to him self-evident, for be does not even raise the question. "If you romanticists really wanted to preserve the good old time, with all its attendant features, thatched roofs, loss of time, and smells, then, though I should not join you, I should respect you as privileged and interesting eccentrics. But you don't want this at all! And, indeed, you could not! You could not because you yourselves would be much too poor for this new, pretentious present. Therein lies coercion for you 
too, and the more so since after the war there will be much to pay. With rising prices it is impossible to be an economic romanticist without sinking in the social scale" (p. 140).

As a corollary to this argument he adds that not the whole soul will be required of the new partners. They may keep their music and their art, they may make it their mission to add to the "hard North German civilisation that touch of charm which will make it tolerable to the outside world "(p. 141). It is definitely implied, however, that this concession must be paid for, will be entered on the balance sheet as part of the purchase money.

Here we seem to come to the problem of Alsace-Lorraine. ${ }^{1}$ Of the Reiohsland, be it noted, there is little said in the book. There are certain oblique allusions both to it and to Poland, but Naumann carefully avoids mentioning the fact that if Bavaria and Wurtemberg have yielded, Alsace-Lorraine and Poland have not. Why? Why has the Alsatian, despite all that he has gained materially from the Treaty of Frankfurt, stood obstinately aloof? Why does he continue to present to the immigrant Prussian that spirit of mockery against which the latter's heaviest guns are of no avail? Clearly because he has behind him a tradition, based upon local place relations and upon the historical link with the France of the Revolution, which cannot be overthrown. The docile incomer, often an East Prussian, sure, not of himself, but of the superstate behind him, finds that he can neither impress nor convince the Alsatian. Nay more, he himself, if all tales be true, is puzzled and confused, shaken in his faith, by a resistance against which the weapons whose use he learnt in school and barrack, are helpless. Sent to convert, he is sometimes himself converted. To the Alsatian, more experienced in all the arts of life, he seems but a servile soul, constrained at his worst to cut open the heads of helpless cripples because it appears to him the only real way of showing that he is a man. The Reichslander feels that to those who through many generations bave lacked sufficient bread, even of the coarsest kind, material prosperity may seem: the greatest good. But to those who upon an old tradition of comfort have built an ordered, localised life, joy, satisfaction of the finer instincts, individualisation are necessary, and against this spirit the Prussian officer's sword is helpless.

The tradition of grinding poverty, as we have suggested, was once widely sproad in parts of this country, still lingers in some places. But the material comfort brought by industrialisation has had already time to become a tradition; and upon it as a basis a new spiritual life is beginning to grow up. The Lancashire millowner is beginning to utilise his surplus wealth in the service of his city, if not of the state. The Northumberland pitman now earns in the pit not only his daily bread, for that he should ever come to lack that has not occurred to him, but leisure for self-development; and he is fumbling, if in an uncertain fashion, after means which will ensure this. The Provençal, even though his material prosperity has been badly shaken by the indirect effects of the industrial 
revolution elsewhere, still gets from his land, as he has always got, not only the essentials of material well-being, but, in the more delicate and intricate agricultural operations to which his soil lends itself, opportunities for tasting at least the joys of individual creative work.

Upon this world, with its admixture of old and new, with its variability, its individuality, produced and maintained by responses to particular environments, the Germans would impose their "new socialeconomic creed," with its deadening uniformity, its denial of personality, its attempt to replace the actual physical world, the world the geographer studies and the poets love, by a new machine-made construction. To the world-resistance they would oppose Prussian militarism. If immediate world domination prove impossible, then at least they must have security, forgetting that for living things in a changing world there is no security save in death, no chance of survival save in the variability which seems weakness to the short-sighted observer, but which all experience proves to be strength.

In an earlier period there lived in America the huge, heavily armoured Glyptodon, armed, like the Prussian state, against every foe, to all appearance irresistible. "Nature," says Professor Parker, "seems to have built him, as Rome was built, for eternity." But only his armour and his bones remain in a world which has moved past him. Has Prussia also forgotten that size and might are not all?

To sum up, to the geographer the inward side of the great war is that it is a deliberate attempt on the part of a group of men to emancipate themselves from the control of that changing, local environment which has produced all the life that we know. But in this Prussia has only carried to its utmost limit a line of argument common among those who have become intoxicated with the new powers of machinery, and have thought that with them the heavens could be stormed, the waters turned out of their courses. The bond which links almost all the civilised world against Prussia to-day is largely due to a deep instinct, whose formulation in words is difficult. That instinct may serve to overcome the immediate peril: but unless new ideals can be formulated in a regenerated and sobered world the danger may remain.

\section{METEOROLOGY AND THE WAR. ${ }^{1}$}

WEATHER variations and climatic conditions are obviously of enormous importance in warfare, and many examples could be cited by way of illustration in both ancient and modern history. On the great scale we have at sea the wreck of the Spanish Armada, and on land "the long-drawn agony of the retreat of the Grand Army from Russia in 1812, " which has never been more vividly described than by Alison. Napoleon entered Moscow on 19th October in that year. An unusually

1 Abstract of an afternoon lecture delivered to the Society in Edinburgh, on 14th March 1918, by Mr. Andrew Watt, M.A., F.R.S.E., Secretary to the Scottish Meteorological Society. 